\title{
Implications of the EFQM Model as a Strategic Management Tool in Practice: A Case of Slovak Tourism Sector
}

\author{
Ján Dobrovič \\ Faculty of management, University of Prešov in Prešov \\ Lubomir Kmeco \\ University College of Business in Prague \\ Peter Gallo \\ Faculty of management, University of Prešov in Prešov \\ Peter Gallo, jr. \\ Faculty of management, University of Prešov in Prešov
}

Received: 21 March 2019. Revision received: 14 May 2019. Accepted: 14 May 2019

\begin{abstract}
In this paper, the emphasis is put on the issue of using one of the most comprehensive management tool assessing and improving the overall enterprise performance - the EFQM Excellence Model. The aim of paper was to reveal the use of above mentioned management tool within the 600 tourism-related enterprises operating in Slovakia and identify barriers complicating the application of EFQM Model while managing and improving their overall performance. The research was based on formulated hypotheses, which were verified by appropriate statistical methods, namely the population proportion method and the Chi-square method of independence. Based on the results of H1 verification, the EFQM Model was used by less than $10 \%$ of Slovak tourism-related enterprises. A statistically significant relationship between the size of tourism-related enterprise and the use of EFQM Model, analysed within the H2, was not confirmed. The last analysed $\mathrm{H} 3$ was focused on the form of business ownership and the use of EFQM Model. Also in this case, no statistically significant relationship between these variables was proven. By using the standard deviation method, we found that the lack of financial and personnel resources is one of the greatest obstacles within the application of this model. Our research pointed out the low and insufficient use of the EFQM Model in business practice. Therefore, our intention is to present this model as a modern, innovative management tool assessing not only financial, but also non-financial aspects of the enterprise performance. Mapping the actual use of EFQM Model in Slovak tourism-related enterprises can be considered as one of the most significant findings of this paper, which may form the basis for further research in this area.
\end{abstract}

Key Words: performance, EFQM Model, non-financial indicators, research.

JEL Classification: G21, L26, O16

\section{Introduction}

In today's ever-changing environment, businesses face new challenges that require enterprises to be more flexible and effective. Studies on entrepreneurial learning 
a relatively new development at the intersection of entrepreneurial studies and small business management in which began to emerge as concepts in the late 1990s (Gavurova et. al., 2018). A regional disparity is becoming increasingly important growth constraint. Policy makers need quantitative knowledge to design effective and targeted policies (Štefko \& Steffek, 2018).

The available studies present many different and mutually contradictory factors that need to be taken into account in the strategic decisions of managers. Their importance and intensity are different for individual business entities (Belás et al., 2018). Management standards serve as an effective knowledge diffusion channel, considering that they offer comprehensive scientific and practical knowledge for many different stakeholders (Pohle et al., 2018, Stefko et al., 2016b). With regard to fierce competition, organizations are now putting an increasing emphasis on the intangible value of reputation in order to achieve their goals (Štefko et al, 2016a). The ability of an organization to effectively and effectively operate in a competitive environment is highly dependent on its knowledge capability and innovation performance (Aboelmaged, 2014). The Internet has also brought significant changes for companies operating in a constantly changing world creating new challenges and opportunities (Bacik et al., 2019). The technological advancements in the globalizing world and the rapid change in socio-economic conditions result in the increase of customer's demands and expectations (Tuzunkan, 2018). People use the perks of tourism industry to explore new destinations, however, doing sports in a healthy environment is also becoming increasingly popular. In these days, tourism is being combined with physical activities, thus enabling the population to enjoy both active and passive relaxation. Nowadays, tourism is also connected with the health care sector as customers seek sports as their leisure time activity (Šip, 2017). Entrepreneurs must respond to constantly changing market situation and be able to adapt to these changes professionally. If a business wants to be successful, it should not focus solely on financial side of the business, but also on more flexible factors like non-financial indicators. These aspects include, in particular, the ability to learn, the innovative thinking of employees, the use of available information, the ability to continually improve relationships with customers or suppliers. There also exist international standards that aim to systematize the implementation of business management systems (da Fonseca, 2015). In this context, it is important to focus on managing and measuring business performance. Our paper focuses on the EFQM model, which we will analyse through a questionnaire survey carried out in selected enterprises. Business excellence assessments - such as those proposed by the European Foundation for Quality Management and the administrators of the Malcolm Baldrige National Quality Awardhave enabled many organizations to identify key areas for improvement, ranging from the role of leadership in developing a service-oriented culture (Dubey, 2016). The EFQM model is a modern and system-oriented method for managing and improving business performance and contains a range of factors that include not only financial but also non-financial indicators.

In our paper, we decided to focus on exploring the EFQM model in the tourism business, as tourism is one of the most important sectors of the world economy. Improving the overall results in the tourism also depends on the appropriate choice of methods supporting the performance improvement of tourism enterprises (Gallo et al., 2019). 


\section{Literature review}

The generic nature of business excellence models and arbitrary approaches followed by organizations to achieve excellence has triggered new approaches to attain excellence (Dubey \& Lakhanpal, 2019). The EFQM Excellence Model (EEM) has been used by managers and academics as a proxy for the implementation of total quality management (TQM) (Gomez et al., 2017). Empirical studies that examined the relationship between overall quality management (TQM) and organization performance examined the impact of each TQM dimension, including the EFQM model, on performance separetely (Calvo-Mora et al., 2014). The EFQM Excellence Model was created in 1991 in collaboration with the founding members of the European Quality Foundation. It is a comprehensive management tool used to assess and improve the performance of a broad range of business activities. In Europe, quality management is carried out according to a model formulated by the European Quality Management Foundation (European Foundation for Quality Management - EFQM). It is also known as EFQM Excellence Model (Al-Tabbaa et al., 2013; Bolboli \& Reiche, 2014). When appropriately implemented, excellence EFQM business excellence model aid enterprise quests for sustained superior results across varied dimensions (Edgerman, 2018). This European Excellence Model is suitable to be used by any business seeking to continually improve its performance. It enables a complete analysis of the processes and activities that take place in the enterprise at all levels with the participation of all employees and identifies the areas that need to be improved. Since its inception, the model has been revised and refined several times. The model consists of nine criteria. An important element of EFQM is a continuous improvement using available management tools and techniques. Quality Control Piliers (EFQM), as the latent factor of "excellence enabling", is linked to business performance, taking into account the mediating role of innovation in this relationship (Kafetzopoulos, 2019). The model consists of nine criteria, five assumptions of excellence and four results. The tool is based on the principle that five performance assumptions, leadership, employees, strategy, partnerships and resources and processes lead to exceptional organizational performance results based on the relations to employees, customers, companies and business results (Simonova \& Fomenko, 2017, Mad'arová, 2007). Model EFQM Excellence is a tool designed to comprehensively assess an enterprise and its performance. It emphasizes the role of leadership in business, the policy and strategy used, the impact on employees and the resources used by the partnerships as prerequisites for the good functioning of processes. These processes result in a relationship with customers, employees as well as the relationship with the enterprise. This model respects several principles, with the greatest emphasis being placed on the principle of continuous improvement. Continuous improvement concerns all business activities that can be achieved using available modern management methods and proven practices, and thus ensure the future of the enterprise. The model eliminates duplications, identifies existing deficiencies, and understands their stronger sides. A significant feature of the EFQM model is that it provides people with broader and deeper insights into the cause and effect of relationships between their organization activities and the results it achieves (Al-Majali \& Almhirat, 2018).

While the EFQM model was primarily designed for European enterprises, the US uses the Malcolm Baldrige National Quality Award (MBNQA), which includes seven exceptional performance criteria, namely Leadership, Strategic Planning, Customer Orientation and Market, Measurement, Analysis and Knowledge 
Management, Human Resources, Process Management and Business Performance Results (Talwar, 2011).

The EFQM model has also been the subject of various research related to its use, in particular in relation to the Total Quality Management (TQM) concept (Calvo-Mora et al. 2015). The KPI institute carries out strategic management research that includes the EFQM model. The mentioned model is regularly placed in the list of the most used management tools. The 2017 Bain \& Company research carried out on a sample of 1,200 enterprises around the world showed that the TQM model, with which the EFQM model is linked, is used by up to $43 \%$ of enterprises. The TQM model is thus placed in the list of top ten most used tools to improve business performance (see Graph 1).

Graph 1 The most used management tools

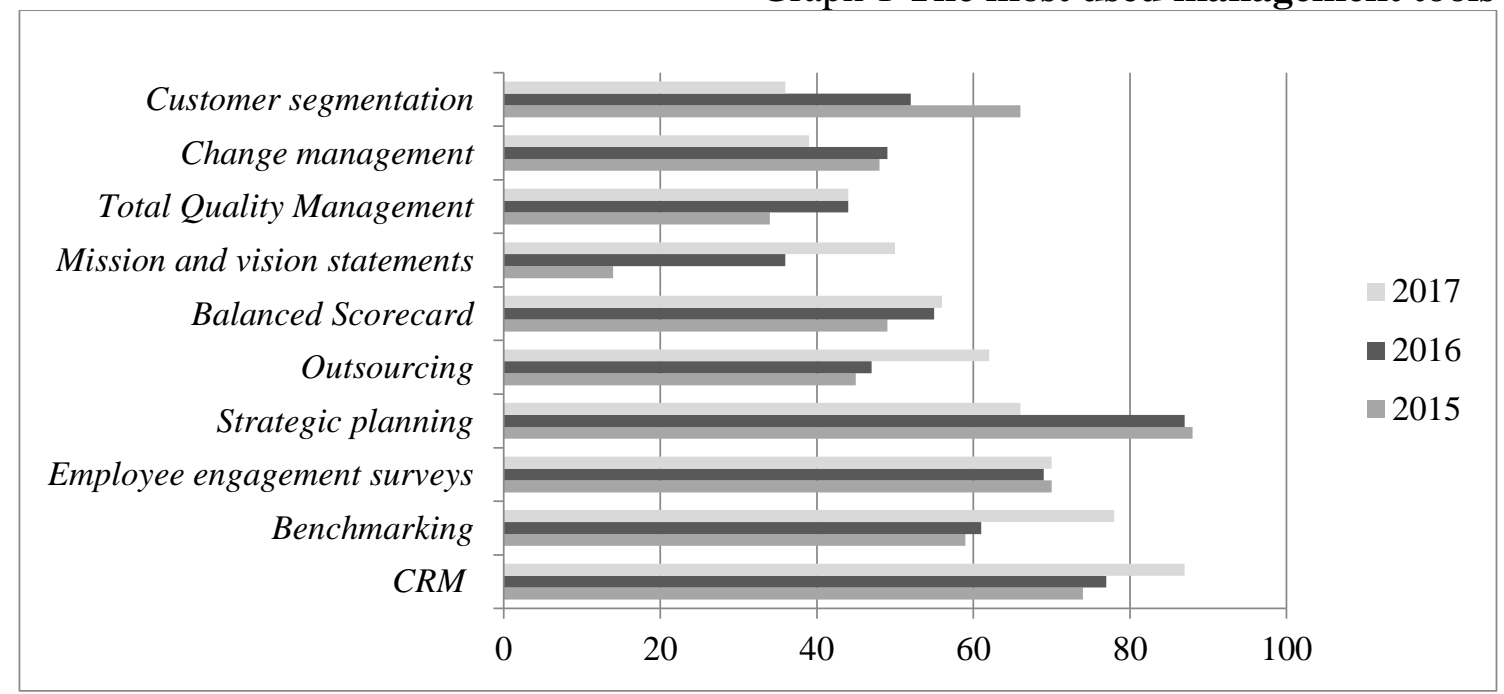

Source: own elaboration by Bain \& Company (2018)

The countries of Central and Eastern Europe have different approach, however. Veselová (2018) carried out research in Lithuania. The results show that the EFQM model is being used by $25 \%$ of large and $10 \%$ of small and medium-sized enterprises. Compared to Western Europe, this figure is much lower. Research carried out by Stríteská \& Svoboda (2012) pointed to even lower values - only 3\% of Czech companies use the EFQM model despite the fact that up to $29 \%$ of respondents use quality management tools. The authors also report that, according to statistics, this model is being used by more than 30,000 enterprises across Europe.

The area of our research was focused on the issue of strategic management methods using financial as well as non-financial indicators. In this context, the use of EFQM Model can be compared with the Balanced Scorecard concept. Bain \& Company, a consultancy company, regularly conducts a worldwide survey concerning the top management tools used in business practice. Based on the results in 2018, the Balanced Scorecard was applied in 53\% of enterprises. As reported by company Gartner (2018), about half of the analysed enterprises use the above mentioned concept. This finding was also confirmed by research of Rigby \& Bilodeau (2014), according to which the concept is applied in $48 \%$ of large and medium-sized enterprises. In Slovakia, the research study focused on the use of Balanced Scorecard concept was carried out by authors Lesáková et al. (2017). Based on the results, only $9.15 \%$ of the analysed companies used this modern concept. 


\section{Methods}

The paper presents research focused on the use of the EFQM model in tourismrelated enterprises in Slovakia. Through research we want to point out its low use rate. The paper also deals with factors that prevent the use of the EFQM model in tourismrelated enterprises. The aim of the paper is also to introduce the EFQM model, which we describe as a comprehensive management tool that assesses and improves the performance of a wide range of business activities. The main aim of the research was supported by sub-aims, namely the use of EFQM in tourism-related enterprises and the demonstration of a statistically significant relationship between the size of enterprises (by number of employees) and the size of sales and the use of EFQM.

To get the data we chose to employ the questionnaire method, which we consider to be a suitable tool for obtaining the required information. The questionnaire was created in the online environment using google forms. The questionnaire consisted of closed questions and the questions using the Likert scale. The Likert scale consists of answers ranging from "completely agree" to "completely disagree".

The questionnaire consisted of two basic parts. The first part aimed at identifying basic data and the second part on the research itself. The identification part focused on issues related to the size of enterprise, ownership scheme and geographical scope. The questions in the second part of the questionnaire focused on the research itself and were divided into three parts. The first part of the questionnaire's research part focused on the strategy of the company. The second part focused on the performance of enterprises, and the third part focused on the EFQM model itself, which we tried to investigate in more depth using the chosen questions. Questions focused on the level of use of EFQM in tourism-related enterprises and the reasons why enterprises do not use this model.

Our research focused on enterprises operating in the field of tourism, which we addressed through the questionnaire. We applied the probability theory on the sample. Thus, we confirmed that the results can be generalized to a basic set. We analyzed these results even further. In the research, we applied the method of random selection, thus eliminating the possibility of distortion of results. This means that every enterprise in a core file may become a sample file. Each method has its own rules. The rules for random selection must be set so that each element has the same chance to make it to the selection file. The classification of tourism-related enterprises was based on the methodology and classification of enterprises NACE and SK NACE. SK NACE is the standard classification of economic activities used in the European Union. The database of tourism-related enterprises we used in our research was obtained from the Index Entrepreneur website. The Entrepreneur Index project is a database of enterprises whose main task is to support and develop a transparent business environment in Slovakia. All information which the Entrepreneur Index uses is drawn from publicly available databases and registers. The basic information framework consists of digitally structured data, files in pdf, csv, xls and electronic scans of various documents. The questionnaire was sent to 619 tourism-related enterprises. We got back 60 questionnaires, the return rate of $9.85 \%$. Almost a $10 \%$ return rate is standard in the questionnaire research and we consider the results of this research to be relevant.

The research sample consisted of tourism enterprises mostly represented by medium-sized enterprises (45\%). The number of small and large enterprises included in the research was almost equal. A total of $22 \%$ of small enterprises, $25 \%$ of large enterprises and only $8 \%$ of micro enterprises participated in the final survey. In terms of 
the form of business ownership, $48 \%$ of the analysed enterprises were owned by Slovak investors, $50 \%$ was made up by foreign investors and remaining $2 \%$ were in the form of mixed ownership.

The hypotheses were formulated on the basis of literature review processed from scientific papers described within the evaluation of individual hypotheses as well as from companies such as Bain \& Company (2018), Gartner (2018) dealing with strategic management issues.

The questionnaire and the overall research on the EFQM model were based on the following hypotheses:

H1: We assume that more than $10 \%$ of tourism-related enterprises use EFQM as a comprehensive management tool to boost business performance.

H2: We assume that there is a statistically significant relationship between the size of the tourism-related enterprise and the use of EFQM.

H3: We assume that there is a statistically significant relationship between the ownership of the tourism-related enterprise and the use of EFQM.

Research methods such as descriptive statistics, pivot tables, etc. were used to evaluate the data obtained, using analysis, comparison, synthesis, selection, induction and deduction. To verify the hypotheses, we used the population proportion method and the Chi-square method of independence. We tested the hypothesis using the Chi-square test in the Statistica statistical program by StatSoft, version 12.0.

Table 1 Used formulas with explanatory note

\begin{tabular}{|c|c|c|}
\hline Indicator & Formula & Explanatory note \\
\hline $\begin{array}{c}\text { Pearson's } \\
\text { Chi-square } \\
\text { Test of } \\
\text { Independence }\end{array}$ & $\chi^{2}=\sum \frac{\left(f_{e}-f_{t}\right)^{2}}{f_{t}}$ & $\begin{array}{l}\chi^{2}-\text { the Chi-square value subsequently compared to } \\
\text { a table value based on the selected error } \\
\text { probability, } \\
\mathrm{f}_{\mathrm{e}}-\text { the empirical frequency of observed variables, } \\
\mathrm{f}_{\mathrm{t}}-\text { the theoretical frequency of observed variables. }\end{array}$ \\
\hline $\begin{array}{l}\text { Population } \\
\text { proportion } \\
\text { method }\end{array}$ & $\mathrm{p}=\widehat{\mathrm{p}} \pm \mathrm{z}_{\alpha} * \sqrt{\frac{\hat{p}^{*} \hat{\mathrm{q}}}{\mathrm{n}}}$ & $\begin{array}{l}\hat{\mathrm{p}}-\text { the proportion of the phenomenon in the selected } \\
\mathrm{q}-\text { the proportion of the opposite phenomenon in the } \\
\text { selected sample, } \\
\mathrm{n}-\text { size of sample, } \\
\mathrm{z}_{\alpha}-\text { reliability. }\end{array}$ \\
\hline
\end{tabular}

Source: own elaboration by Marcheová et al, 20111

\section{Results}

The research was carried out in tourism-related enterprises in Slovakia and focused on the usage rate of the EFQM model to manage business performance. This model represents a tool for stakeholders to comprehensively assess performance of the enterprise. The first goal of our research was to find out what is the use rate of the EFQM model in tourism-related enterprises in Slovakia. The relevant hypothesis also features an assumption that we derived from research that was carried out in the Czech Republic by the researchers Stríteská \& Svoboda (2012). Their research showed that only $3 \%$ of enterprises use EFQM in the Czech Republic. In our research, we decided to find out what the current situation in Slovakia is in relation to the above. Therefore, we set the following hypothesis: 
H1: We assume that more than $10 \%$ of tourism-related enterprises use EFQM as a comprehensive management tool to boost business performance.

To verify the hypothesis, we used a statistical method to determine the proportion of the phenomenon in the population. The results are shown in Table 2.

Table 2 Using EFQM model

\section{Population proportion method}

\begin{tabular}{c|c}
\hline & $\mathrm{p}=0.1833 \pm 1.96 * \sqrt{\frac{0.1833 * 0.8166}{60}}$ \\
$\hat{\mathrm{p}}=0.1833$ & $\mathrm{p}=0.1833 \mp 0.0499$ \\
$\hat{\mathrm{q}}=0.8166$ & $0.0854 \leq \mathrm{p} \leq 0.2812$ \\
& \\
\hline
\end{tabular}

Source: own elaboration

Using the population proportion method, we evaluated the hypothesis aimed at using the EFQM model, where we reached values from $8.54 \%$ to $28.12 \%$. The resulting values were obtained by using the variables put into the formula. These values resulted in three basic variables. The first variable stated the percentage of tourism-related enterprises using the EFQM. The second variable stated the opposite - enterprises that do not use the EFQM model. The last variable contained data on the total number of respondents who participated in our research. The test reliability coefficient was determined as well, reaching the value of 95\% (coefficient 1.96). Graph 2 shows the percentage display of results from the data obtained.

Graph 2 Comparing the assumption with the use of EFQM Model

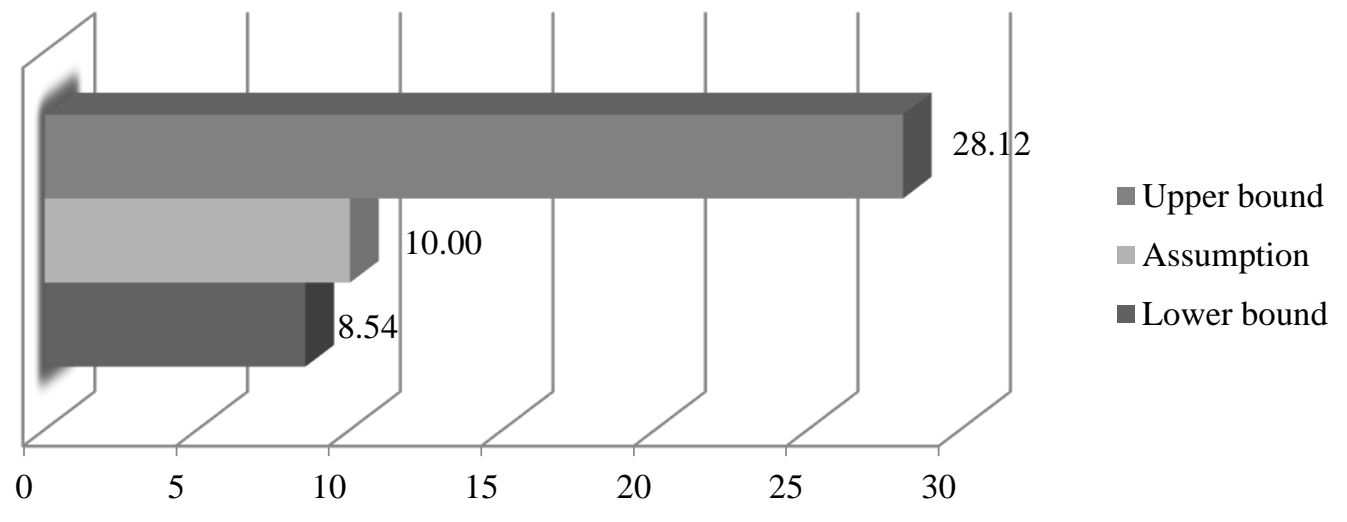

Source: own elaboration

By verifying the hypothesis using the population proportion method, we reached values below our assumption (below 10\%). Based on the above facts, we can say that the EFQM model is used by less than $10 \%$ of tourism-related enterprises operating in Slovakia. Thus, we note that the hypothesis has not been confirmed and is thus not accepted.

The second hypothesis was based on data from The KPI Institute (2017), which states that the EFQM model is mostly used by companies with a higher number of employees. In our research, we focused on this fact and set the hypothesis by which we 
verified the dependence between the size of the tourism-related enterprise and the use of the EFQM model:

H2: We assume that there is a statistically significant relationship between the size of the tourism-related enterprise and the use of EFQM.

In this case, we have only processed data from respondents who use the EFQM model. To verify this hypothesis, we chose the Pearson Chi-square test of independence. Through this test, we calculated the Chi-square characteristic which we then compared with the critical table value for our chosen error probability and the degree of freedom. Table 3 shows the test results.

Table 3 The results of testing hypothesis

\begin{tabular}{|l|c|c|c|}
\hline \multicolumn{4}{|c|}{ Pearson's Chi-square Test of Independence } \\
\hline & O15_PREK & O15_PREK & Row \\
\cline { 2 - 4 } & G_1:1 & G_2:2 & Totals \\
\hline G_1:1 & 18.1864407 & 10.81356 & 30 \\
\hline G_2:2 & 18.8135593 & 11.18644 & 30 \\
\hline All Groups & 37 & 23 & 60 \\
\hline Calculated value & \multicolumn{3}{|c|}{$\mathrm{p}=0.0919$} \\
\hline Error profitability & \multicolumn{3}{|c|}{$\alpha=5 \%(0.05)$} \\
\hline Degree of freedom & DF $=1.00$ \\
\hline Critical value & $\mathrm{x}^{2}=0.01$ \\
\hline
\end{tabular}

Source: own elaboration

The results of the verification of the hypothesis are shown in Graph 3 in the form of a Scatter plot that displays the values for the two variables examined from a set of enterprise data. The graphical representation of the EFQM model depends on the size of the enterprise by the number of employees.

Graph 3 Dependence between enterprise size and use of EFQM

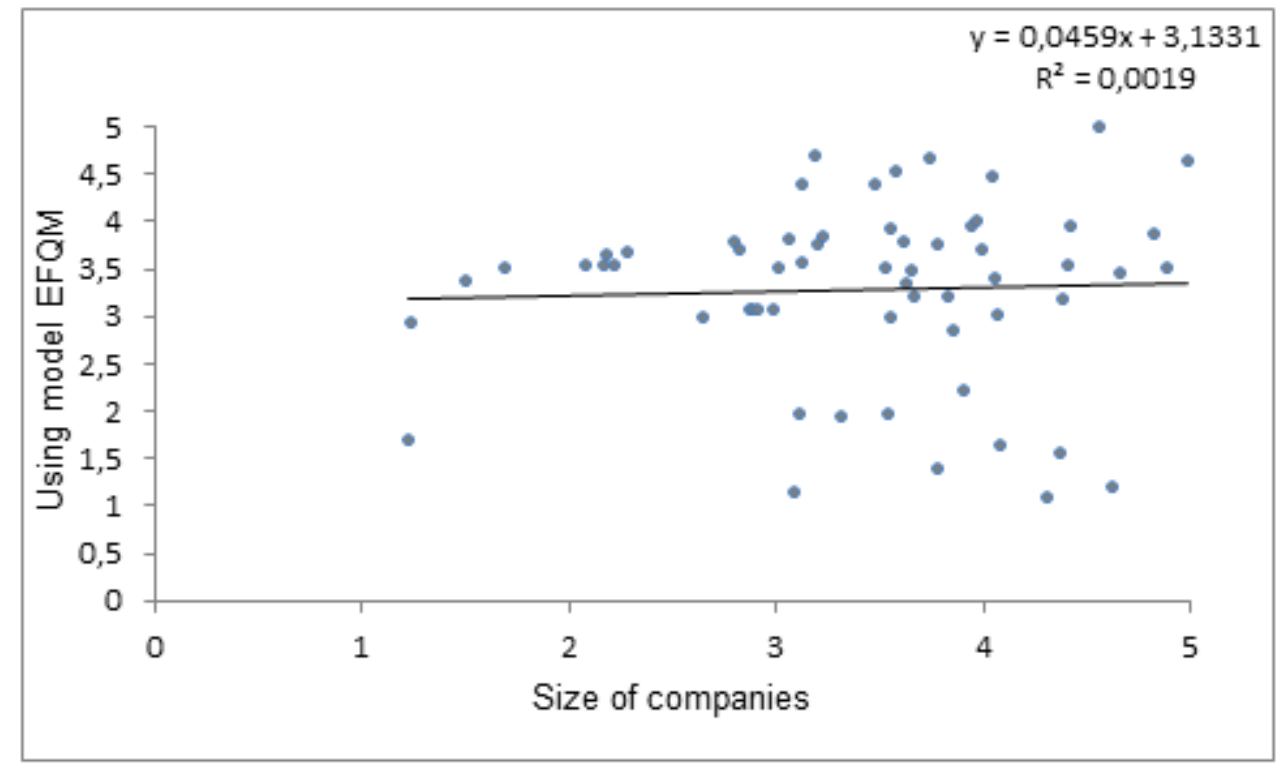

Source: own elaboration

By verifying the hypothesis through the Chi-square test of independence, we can conclude that the size of a tourism-related enterprise does not affect the use of the 
EFQM model and there is no statistically significant relationship between these. This statement is proven by the $\mathrm{p}$ value which is greater than 0.05 . Therefore, we do not accept the hypothesis.

The third hypothesis focuses on the ownership of tourism-related entities. Here we were interested in whether the form of ownership affects the introduction of the EFQM model. We based our assumption on research of Veselova (2018), who states that up to $25 \%$ of large enterprises in Lithuania uses the model. Therefore, we were wondering if foreign-owned enterprises tend to use the EFQM model to a greater extent. The hypothesis was determined as follows:

H3: We assume that there is a statistically significant relationship between the ownership of the tourism-related enterprise and the use of EFQM.

To test this hypothesis, we used Pearson's Chi-square independence test based on data from companies that use EFQM. Table 4 contains the test results.

Table 4 The results of testing hypothesis

\begin{tabular}{|l|c|c|c|}
\hline \multicolumn{4}{|c|}{ Pearson's Chi-square Test of Independence } \\
\hline & O15_PREK & O15_PREK & Row \\
\cline { 2 - 4 } & G_1:1 & G_2:2 & Totals \\
\hline G_1:1 & 21.2864518 & 12.92356 & 30 \\
\hline G_2:2 & 15.7135482 & 10.27644 & 30 \\
\hline All Groups & 37 & 23 & 60 \\
\hline Calculated value & \multicolumn{3}{|c|}{$\mathrm{p}=0.0722$} \\
\hline Error profitability & $\alpha=5 \%(0.05)$ \\
\hline Degree of freedom & \multicolumn{3}{|c|}{$\mathrm{DF}=1.00$} \\
\hline Critical value & $\mathrm{x}^{2}=0.01$ \\
\hline
\end{tabular}

Source: own elaboration

The above hypothesis was verified similarly to the previous ones based on the Scatter plot (Graph 4), in which we examined two variables from a set of data obtained from tourism-related enterprises. The EFQM model is outlined in relation to the form of business ownership. The scatter plot does not show any dependence in this case, which is also confirmed by the statistically proven hypothesis that the form of business ownership does not affect the use of EFQM in tourism-related enterprises.

The $\mathrm{p}$ value of the Chi-square test of independence is greater than 0.05 . Therefore, we can state that there is no statistically significant relationship between the ownership of the business and the use of the EFQM model and that the form of ownership does not affect whether the business uses the EFQM model. Thus, the hypothesis is not accepted.

Our research has found that the use rate of the EFQM model is still relatively low. We were interested in the reasons why entities do not use the model (outlined in the questionnaire). These questions and answers were then processed using statistical methods and displayed in Table 5. 
Graph 4 Dependence between business ownership and use of EFQM

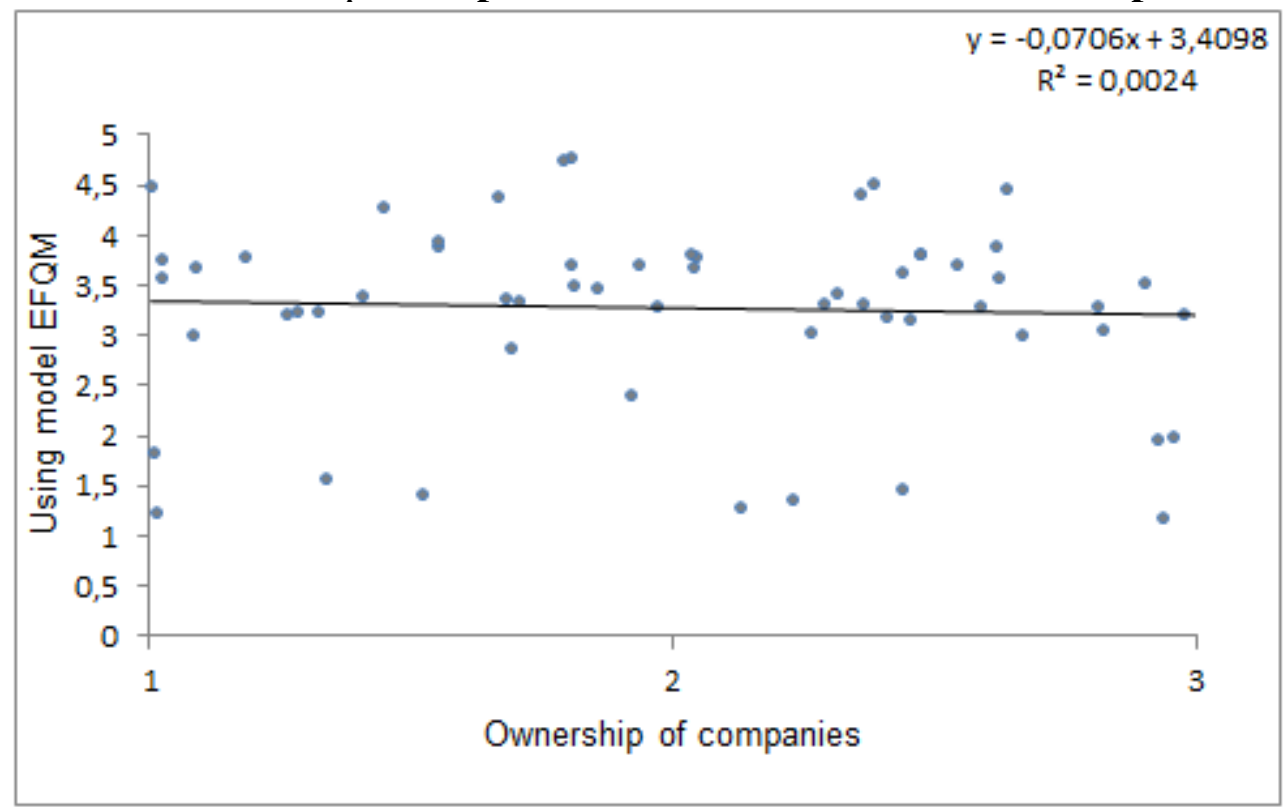

Source: own elaboration

Table 5 Reasons for not using EFQM

\begin{tabular}{|l|c|c|c|c|c|c|}
\hline \multicolumn{1}{|c|}{ Reason } & Avg. & Min. & Max. & $\begin{array}{c}\text { Standard } \\
\text { deviation }\end{array}$ & $\begin{array}{c}\text { Most } \\
\text { common } \\
\text { answer }\end{array}$ & $\begin{array}{c}\text { Frequency of } \\
\text { occurrence of the } \\
\text { most common } \\
\text { answer }\end{array}$ \\
\hline Lack of financial resources & 4 & 2 & 5 & 1.12 & 4 & 13 \\
\hline Lack of personnel & 3 & 1 & 5 & 1.14 & 3 & 9 \\
\hline $\begin{array}{l}\text { Difficulty in introducing } \\
\text { the model into } \\
\text { management }\end{array}$ & 2 & 1 & 4 & 1.26 & 2 & 7 \\
\hline $\begin{array}{l}\text { Inability of reaching } \\
\text { agreement between } \\
\text { managers }\end{array}$ & 3 & 2 & 5 & 1.16 & 4 & 10 \\
\hline $\begin{array}{l}\text { The enterprise is not } \\
\text { interested in introducing } \\
\text { the model }\end{array}$ & 3 & 1 & 5 & 1.18 & 3 & 8 \\
\hline
\end{tabular}

Source: own elaboration

Questions aimed at getting information on the use of the EFQM model in tourism-related entities were formulated based on the Likert scale model. The respondents were able to choose answers ranging from "totally disagree" to "totally agree". Based on the obtained data we conclude that the lack of financial resources is considered the greatest obstacle for not using the EFQM model. In particular, entities spend their money on day-to-day operations, and spending money on new models or innovative approaches is not interesting for them. Another important reason for not 
using the EFQM model is the lack of personnel. The management of entities is, however, aware of the fact that in order for the model to succeed they need skilled employees. Attracting such employees is also closely related to the financial costs, because it is important to pay those employees accordingly. The possible reasons for not introducing the model into the management of the entity also include the personal interests of managers and the consequent inability to agree on the introduction of the model. There are also tourism-related entities that are not interested in this model. The least frequently mentioned reasons for not using the EFQM model was the difficulty of introducing the model into the management. It should be noted that external consultancy companies may help with putting this model into operation. They know how to deploy the model and prepare employees for its operation and proper use. We compared the reasons that prevent businesses from using the EFQM using a standard deviation (Graph $5)$.

Graph 5 Comparison of the average trend and the standard deviation

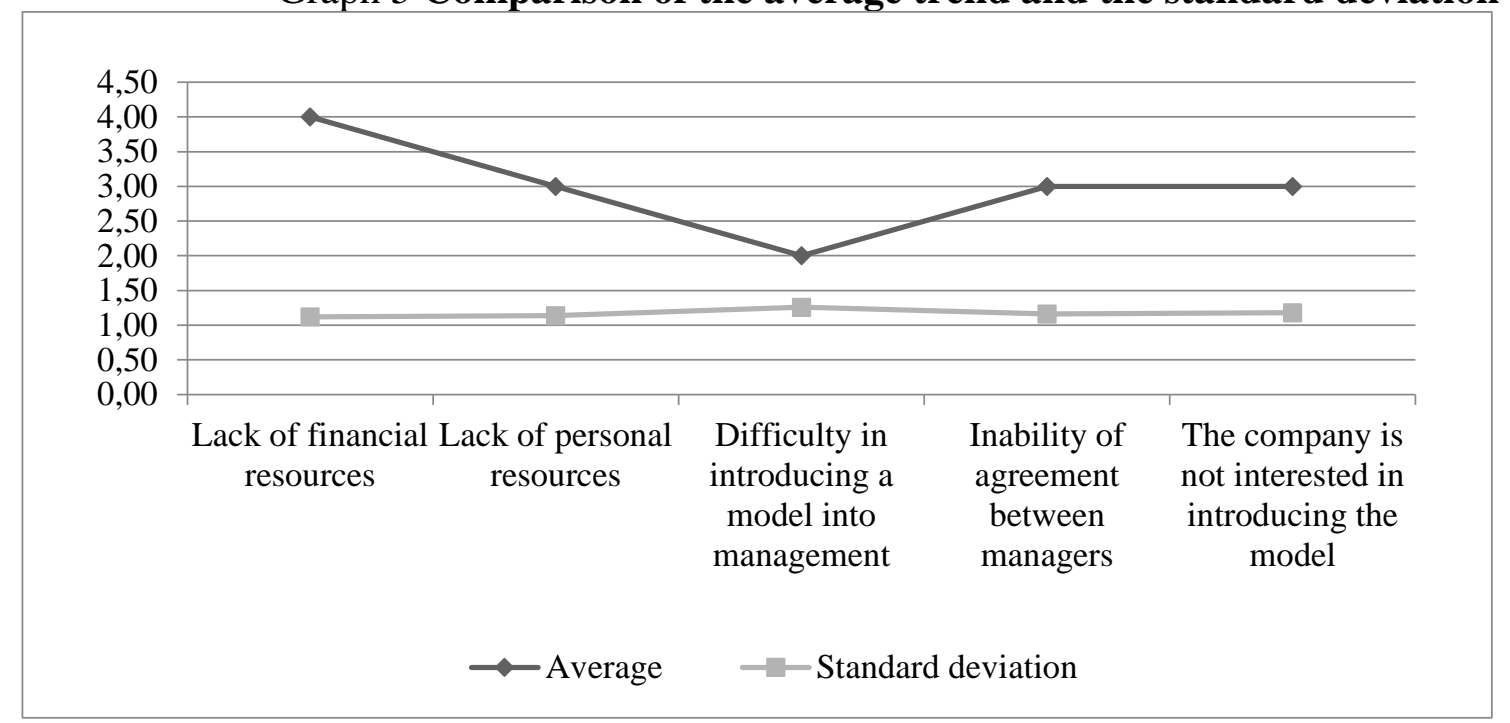

Source: own elaboration

The standard deviation shows lower values for financial and personnel resources and gradually rises with the presence of less important factors. Thus, financial and personnel resources can also be seen as the most important factors preventing the use of the EFQM model in tourism-related entities.

\section{Discussion}

Our research showed that tourism-related entities use the EFQM model to a very small extent. Its usage rate is below $10 \%$. What is interesting, however, is that the size of the entity and form of ownership do not have a significant impact on the use of the model. The main barriers to using the EFQM model in tourism-related entities are financial and personnel resources. Investing in the right personnel is worth the business, because only qualified and skilled people can ensure the proper implementation of innovative models that will bring about competitive advantage.

Of course, this research paper contains several limitations. The research sample was limited only to the area of tourism, which differs significantly from e.g. industry. In this regard, the final results can be different. Moreover, the return rate of questionnaires 
was at the level of $10 \%$, so no comprehensive results were provided. Based on the above mentioned limits, our future research will be focused on the analysis of strategic and performance management issues within the other industries. Our intention is to extend the research sample to get relevant results applicable to the selected industry.

\section{Conclusion}

The enterprise performance is determined by rising financial entitlements, which are (to some extent) the result of globalization, interdependence and internationalization (Onuferová \& Čabinová, 2018). Enterprises are largely managed through financial indicators, but the current trend is showing an increasing importance of non-financial measurers, too. A number of complex systems have been developed to measure business performance, including both financial and non-financial management indicators (Dobrovič et al., 2018a). In the context of profound social, economic and financial changes, private and public organizations managers turn their attention towards the most valuable resource they have - the human resource (HR), the one that can ensure increased organizational performance. Using adequate HR policies and practices, organizations can build a positive work environment that sustains employees' development, encourages communication, innovation, and pro-active attitudes and behaviours (Ciobanu, 2019). Expressing respect, esteem, encouragement, selfassessment is characterized by the form of evaluation support (Balogová et al., 2018). The use of the EFQM model has resulted in an improved view of the firm as a whole, improved internal efficiency and an improved decision-making process. It has also had a notable influence on leadership, motivation and internal communication (HerasSaizarbitoria et al., 2011). The EFQM model will help to achieve a competitive advantage with a strong impact on overall quality management, helping to benefit all interest groups (Nguyen \& Chau, 2017). An integrated quality management system is a key difference for companies, but because each company has its own conditions and its own factors must adapt these businesses to existing models or invent their own system (Golowko et al, 2017). Enterprises will soon realize that using only financial indicators will not help them survive among stronger competition, and that such a strategy is inappropriate for future-oriented enterprises, too. As a result of failing to innovate, the enterprise loses its ability to compete because it insufficiently invests in non-material areas of business. Such areas include, in particular, product and process innovation, investment in employees' skills, motivation and customer satisfaction. Investing in new products, new techniques, and practices worsens the company's short-term financial results. Also, investments in human capital and employee training negatively impact short-term financial results. However, this does not mean that the enterprise will get into trou-ble because of that. In the long run, this investment will bring profits and increase the value of the business - which is the main objective of the business owners after all (Dobrovič et al., 2018b).

\section{Acknowledgment}

The contribution is the result of Vega project no. 1/0194/19 "Research on process-oriented management of financial management focusing on detection of tax evasion in terms of international business". 


\section{References}

1. Aboelmaged, M. G. (2014). Linking operations performance to knowledge management capability: The mediating role of innovation performance. Production Planning and Control, 25(1), 44-58. doi: 10.1080/09537287.2012.655802

2. Al-Majali, B. \& Almhirat, M. (2018). The role of European Foundation For Quality Management EFQM) in improving public sector efficiency and it's impacts on customer satisfaction employees results and corporate image. International Journal for Quality Research, 12(3), 593-608.

3. Al-Tabbaa, O., Gadd, K. \& Ankrah, S. (2013). Excellence models in the nonprofit context: Strategies for continuous improvement. International Journal of Quality and Reliability Management, 30(5), 590-612. doi: 10.1108/02656711311315521

4. Bacik, R., Kmeco, L., Fedorko, R., Olearova, M. \& M. Rigielsky (2019). Marketing Instrument of Improving Hotel Management Service: Evidence of Visegrad Group Countries. Marketing and Management of Innovations, 1, 208-220. doi: http://doi.org/10.21272/mmi.2019.1-17

5. Balogova, B., Lovasova, S. \& Lukacova, V. (2018). Social loneliness and social support in the elderly. Ad Alta-Journal Of Interdisciplinary Research, 8(2), $158-160$.

6. Bain \& Company (2018). Management Tools \& Trends. Retrieved from: http://www.bain.com/publications/business-insights/management-tools-andtrends.aspx

7. Belas, J., Gavurova, B. \& Toth, P. (2018). Impact of selected characteristics of smes on the capital structure. Journal of Business Economics and Management, 19(4), 592-608

8. Bolboli, S. A. \& Reiche, M. (2014). Culture-based design and implementation of business excellence. TQM Journal, 26(4), 329-347. doi: 10.1108/TQM-012014-0015

9. Calvo-Mora, A., Picón, A., Ruiz, C. \& Cauzo, L. (2014). The relationships between soft-hard TQ factors and key business results. International Journal of Operations and Production Management, 34(1), 115-143. doi: 10.1108/IJOPM09-2012-0355

10. Calvo-Mora, A., Picón-Berjoyo, A., Ruiz-Moreno,C., \& Cauzo-Bottala, L., (2015). Contextual and mediation analysis between TQM critical factors and organisational results in the EFQM Excellence Model framework. International Journal of Production Research, 53(7), 2186-2201. doi: 10.1080/00207543.2014.975859

11. Ciobanu, A., Androniceanu, A. \& Lazaroiu, G. (2019). An integrated psychosociological perspective on public employees' motivation and performance (Short Survey). Frontiers in Psychology, 10(22). doi: 10.3389/fpsyg.2019.00036

12. da Fonseca, L.M.C.M. (2015). ISO 14001:2015: An improved tool for sustainability. Journal of Industrial Engineering and Management, 8(1), 35-50. doi: 10.3926/jiem.1298

13. Dobrovic, J., Lambovska, M., Gallo, P. \& Timkova, V. (2018a). Non-financial indicators and their importance in small and medium-sized enterprises. Journal of Competitiveness, 10 (2), pp. 41-55. https://doi.org/10.7441/joc.2018.02.03 
14. Dobrovič, J., Urbański, M., Gallo, P., Benková, E. \& Čabinová, V. (2018b). Balanced scorecard concept as a tool of strategic management and its usage in the construction industry. Polish Journal of Management Studies 18 (2). pp. 5972. doi: 10.17512/pjms.2018.18.2.05

15. Dubey, M., Lakhanpal, P. (2019). EFQM model for overall excellence of Indian thermal power generating sector. TQM Journal. doi: 10.1108/TQM-07-20180090

16. Dubey, M. (2016). Developing an Agile Business Excellence Model for Organizational Sustainability. Global Business and Organizational Excellence, 35(2), 60-71. doi: 10.1002/joe.21656

17. Dzurov Vargová, T., Gallo P., Šenková, A. \& Šambronská K. (2018). Manažérske inovácie $v$ turizme a systém manažérstva kvality. Vydavatel'stvo Prešovskej univerzity v Prešove. s. 99.

18. Edgeman, R. (2018). Excellence models as complex management systems: An examination of the Shingo operational excellence model. Business Process Management Journal, 24(6), 1321-1338 doi: 10.1108/BPMJ-02-2018-0049

19. Gallo, P., Gallo, P., Mihalčová, B., Čabinová, V., \& Tomčíková, L., (2019). Aplication of the Balanced Scorecard as a strategic management tool in practise: A case of Slovak tourism sector. GeoJournal of Tourism and Geosites, 24(11), 19-28. doi:10.30892/gtg.24102-339

20. Gartner Group (2018). Strategic planning. Available at: https://www.gartner.com/en/insights/strategic-planning

21. Gavurova, B., Belas, J., Kotaskova, A. \& Cepel, M. (2018). Management of education concepts in the field of entrepreneurship of university students in the Czech Republic. Polish Journal of Management Studies, 17(2), 52-62. doi: 10.17512/pjms.2018.17.2.05

22. Golowko, N., Kopia, J., Geldmacher, W. \& Förster-Pastor U. (2017). Comparative study on quality management at German private universities. Quality - Access to Success, 18(157), 85-94.

23. Gómez, J.G., Martínez Costa, M. \& Martínez Lorente, Á.R. (2017). EFQM Excellence Model and TQM: an empirical comparison. Total Quality Management and Business Excellence, 28(1-2), 88-103. doi: 10.1080/14783363.2015.1050167

24. Heras-Saizarbitoria, I., Casadesús, M. \& Marimón, F. (2011). The impact of ISO 9001 standard and the EFQM model: The view of the assessors. Total Quality Management and Business Excellence, 22(2), 197-218. doi: $10.1080 / 14783363.2010 .532330$

25. Kafetzopoulos, D., Gotzamani, K. \& Skalkos, D.(2019). The relationship between EFQM enablers and business performance: The mediating role of innovation. Journal of Manufacturing Technology Management. doi: 10.1108/JMTM-06-2018-0166

26. Lesáková, L., Dubcová, K. \& Gundová, P. (2017). The Knowledge and Use of the Balanced Scorecard Method in Businesses in the Slovak Republic. $E+M$ : Ekonomie a Management, 20(4), 49-58. doi: https://doi.org/10.15240/tul/001/2017-4-004

27. Mad'arová M. (2007). Manažment v teórii a praxi, 3(4), 73-78.

28. Marcheová, D., Tirpáková, A. \& Stehlíková, B. (2011). Basics of Statistics for Teachers. Nitra: UKF. ISBN 978-80-8094-899-3. 
29. Nguyen, V.C., Chau, N.T. (2017). Research framework for the impact of total quality management on competitive advantage: The mediating role of innovation performance. Review of International Business and Strategy, 27(3), 335-351. doi: 10.1108/RIBS-02-2017-0016

30. Onuferova, E. \& Cabinova, V. (2018). Enterprise Performance Analysis of the Selected Service Sector by Applying Modern Methods with an Emphasis on the Creation and Application of the Modified Creditworthy Model (MCWM). Journal of tourism and services, 9(17), 97-122. doi:10.29036/jots.v9i17.74

31. Pohle, A., Blind, K. \& Neustroev, D.,(2018). The impact of international management standards on academic research. Sustainability, 1(12). doi: $10.3390 / \mathrm{su} 10124656$

32. Simonova, A. \& A., Fomenko, S. L. (2017). Evolution of integrated quality management system at higher school. Quality - Access to Success, 18(161). $126-134$.

33. Šip, M. (2017). Sociálna starostlivost' v oblasti duševného zdravia. Sociálna a duchovná revue. 8(2). 29-35.

34. Stefko, R.; Fedorko, R. \& Bacik, R. (2016a). Website content quality in terms of perceived image of higher education institution. Polish journal of management studies. 13(2). 153-163. doi: 10.17512/pjms.2016.13.2.15

35. Stefko, R.; Gavurova, B. \& Korony, S. (2016b). Efficiency measurement in healthcare work management using malmquist indices. Polish journal of management studies, 13(1), 168-180. doi: 10.17512/pjms.2016.13.1.16

36. Stefko, R. \& Steffek, V. (2018). Key Issues in Slow Fashion: Current Challenges and Future Perspectives. Sustainability. 10(7). doi:https://doi.org/10.3390/su10072270

37. Striteska, M. \& Svoboda, O. (2012). Survey of performance measurement systems in Czech companies. E a M: Ekonomie a Management, 15(2), 68-84.

38. Rigby, D. \& Bilodeau, B. (2014). Management Tools and Trends. Available from: <http://www.loyaltyrules.com/management_tools

39. Talwar, B., (2011). Business excellence models and the path ahead. TQM Journal, 23(1), 21-35. https://doi.org/10.1108/17542731111097461

40. The KPI Institute (2017). Strategy and Business Planning. Retrieved from: https://kpiinstitute.org/education/core-programs/

41. Tuzunkan, D. (2018). Undergraduate Tourism Students' Perceptions and Attitudes Towards Tourism Industry: The Case of Daejeon, South Korea. GeoJournal of Tourism and Geosites, 21(1), 103-111. Doi:10.30892/gtg.22204291

42. Veselova, A., (2018). The assessment of European business excellence model criteria performance in Latvian enterprises. Proceedings of the 2018 International Conference "Economic science for rural development" . No 48. 409-418.

\section{Brief description of Author/Authors:}

assoc. prof. Ing. Ján Dobrovič, PhD.

University of Prešov in Prešov, Faculty of management, Department of Management

Konštantínova 16, 08001 Prešov, Slovakia

Email: jan.dobrovic@unipo.sk 
ORCID: https://orcid.org/0000-0002-0637-106X

Main field of research : strategic management, taxes, logistics.

assoc. prof. Ing. Lubomír Kmeco, PhD.

University College of Business in Prague, Department of Tourism

Spálená 76/14, 11000 Praha 1 - Nové Město, the Czech Republic

Email: kmeco@vso-praha.eu

Main field of research: Tourism, impacts of tourism, tourism management.

assoc. prof. Ing. Peter Gallo, CSc.

University of Prešov in Prešov, Faculty of management, Department of Tourism and Hotel Management

Konštantínova 16, 08001 Prešov, Slovakia

Email: peter.gallo@unipo.sk

ORCID: http://www.researcherid.com/rid/G-3981-2018

Main field of research : Human resources, management, controlling.

Ing. Peter Gallo, PhD.

University of Prešov in Prešov, Faculty of management, Department of Management

Konštantínova 16, 08001 Prešov, Slovakia

Email: peter.gallo.1@unipo.sk

ORCID: https://orcid.org/0000-0001-5193-1997

Main field of research : strategic management, leadership, management decisions. 